\title{
University of Technology Sydney
}

\author{
Sue Joseph
}

\section{Found poetry as literary cartography: Mapping Australia with prose poems}

\begin{abstract}
:
Found poetry is lyrical collage, with rules. Borrowing from other writers - from different writings, artefacts, sources - it must always attribute and reference accurately. This paper is derived from the beginnings of a research project into Australian legacy newspaper stories and found poetry as prose poetry, explaining the rationale behind the bigger project. Ethnographic in texture at its edges, the research project sets out to create poetic renditions of regional news of the day, circumnavigating the continent. My aim is to produce a cadenced and lyrical nonfiction transcript of Australian life, inspired by and appropriated from regional legacy media, while it still exists.

The beginning of the research was a recce journey to the centre of Australia in 2016. Currently, the outcomes of the recce are six poems, five of which are nonfiction prose poems. Contextualising found poetry within the prose poetry genre - a long debated and hybrid space - the theoretical elements of this paper underpin its creative offerings.
\end{abstract}

\section{Biographical note:}

Dr Sue Joseph has been a journalist for more than thirty five years, working in Australia and the UK. She began working as an academic, teaching print journalism at the University of Technology Sydney in 1997. As a Senior Lecturer, she now teaches journalism and creative writing, particularly creative nonfiction writing, in both undergraduate and postgraduate programs. Her research interests are around sexuality, secrets and confession, framed by the media; ethics and trauma narrative; memoir; reflective professional practice; ethical HDR supervision; and Australian creative nonfiction. Her fourth book, Behind the Text: Candid conversations with Australian creative nonfiction writers, was released in October 2016. She is currently Reviews Editor of Ethical Space: The International Journal of Communication Ethics.

\section{Keywords:}

Found poetry - Literary cartography - Australia - Prose poetry - Nonfiction poetry 


\section{Introduction}

I am currently developing a research project with the working title Poetic Cartography: mapping Australia on the road. My predominant aim is to create an intersection between found poetry as nonfiction prose poetry, and the daily legacy newspaper stories of regional Australia, through circumnavigation in a set time frame. Academic William Dow writes about 'reconciling the language of information with the language of art through ... poetic profiling' (Dow 2016: 116). Dow writes that Charles Reznikoff gave 'importance... to the materials of daily life, such as newspapers' (Dow 2016: 117); I intend to privilege newspapers and front page headlines as representative of the daily life in regional centres, poetically freezing in time a constrained period of regional front page news events - some every day; some dramatic; some very much hack or sensational journalism - as the ultimate Australian road trip, circumnavigating the continent. My aim is to produce a cadenced and lyrical nonfiction transcript of Australian life, appropriated from regional legacy media, while it still exists. As ButlerKisber writes: 'The rationale for including arts-based representation in qualitative research is that form mediates understanding' (Butler-Kisber 2002: 232). If form mediates understanding, as Butler-Kisber claims, this collection of poems when completed will hold in place the temporal space of the regions and towns we travel to and through, creating a mimetic yet lyrically variant rendition of the news of the day. In Wilkinson and Alizadah's The Realpoetik Manifesto (2012), they advocate 'the potential of poetry to expand our conceptions and perceptions of the "real", Their aim as stated in the manifesto is 'to establish an expansive literary space within which poets can openly engage with auto/biography, history, politics, economics, cultural analysis, science, the environment, and all other aspects of life in the real world' (Wilkinson and Alizadah 2012).

This research project falls into their description of nonfiction poetry, and this paper aims to explain the rationale behind the research project, framed by the conceptual art of 'found poetry' as literary collage or pastiche. The Poetry Foundation, based in Chicago, defines found poetry simply as: 'A prose text or texts reshaped by a poet' (2016). The recently ended online journal The Found Poetry Review, defines it as: 'the literary version of a collage' (2016). And author and poet Annie Dillard calls it 'editing at its extreme; writing without composing' (Dillard 1995: x). She also writes, 'by entering a found text as a poem, the poet doubles its context. The original meaning remains intact, but now it swings between two poles' (Dillard 1995: ix). Hers is the notion which interests me most - doubling, or creating another, or deeper, meaning or reading of a published text; perhaps a more enjoyable means of reading. A new way of seeing.

According to Monte, prose poetry defies definition. He writes it is 'an abstraction meant to question generic boundaries' (2000: 2). Likewise Delville writes: 'To many readers and critics, the prose poem is a piece of prose that wants to be a poem and derives at least part of its meaning from its ability to defeat our generic expectations' (Delville 1998: ix). He writes further of its 'subversive potential', breaking down boundaries 
between 'the lyric, the narrative, the critical essay and a variety of other genres and subgenres'. Edson says, 'The prose poem allows the individual to create his or her own boundaries. It's kind of a naked way to write' (in Johnson 1999). McDowell and Rzicznek call it a positive (as opposed to negative) space, 'populated with elements of poetry - imagery, music, lyricism, metaphor, simile, alliteration, assonance' (2010: xviii). They provide a discrete history of the style, beginning in the Han Dynasty of China (206BCE-220CE) where poets wrote rhymed poems called $f u$ (English translation: rhapsody); through the early nineteenth-century works of French poets Aloysius Bertrand and Charles Baudelaire; to today's growing popularity and breadth (2010: xv). Charles Simic ${ }^{1}$ compares it to food:

an impossible amalgamation of lyric poetry, anecdote, fairy tale, allegory, joke, journal entry, and many other kinds of prose. Prose poems are the culinary equivalent of peasant dishes, like paella and gumbo, which bring together a great variety of ingredients and flavors, and which in the end, thanks to the art of the cook, somehow blend. Except, the parallel is not exact. Prose poetry does not follow a recipe. The dishes it concocts are unpredictable and often vary from poem to poem. (in Lehman 2003: 14-15)

Simic again: 'The prose poem has the unusual distinction of being regarded with suspicion not only by the usual haters of poetry, but also by many poets themselves (in Lehman 2003: 11). Simic went on to win the 1991 Pulitzer Prize for poetry for his text The World Doesn't End, consisting mainly of prose poems. Lehman writes of the work that it can be read as 'dream narratives that end abruptly, enigmatically' (2003: 12). He then gives his own definition of prose poetry, stating: 'The best short definition is almost tautological. The prose poem is a poem written in prose rather than verse ... poetry that disguises its truest nature' (2003: 13).

In its simplest terms, the prose poem privileges the sentence over delineation, utilising poetic and narrative devices. For this paper I intend to offer the beginnings of the research project, contextualised within its theory. This will entail six poetic prose renderings of a reconnoitre trip in mid-2016 to the centre of Australia, examining them as a constrained three-week re-imagined narrative, of both the journey and the regional news of the day. Burdick writes: 'Found poetry is a particular form that can be especially helpful to researchers as a way to resee a static data-driven text' (Burdick 2011: 3). According to Burdick's logic, my selected newspaper headlines and reports provide the 'static data driven text', and the ensuing found poetry, the re-seeing.

\section{Methodology}

The return trip to Central Australia took exactly three weeks, leaving on 4 July 2016 and returning on 25 July. We headed from Sydney towards Port Augusta and straight up the Stuart Highway, through South Australia and into the Northern Territory, turning left at Erlunda for Uluru and Kata Tjuta, arriving on 11 July. En route we camped in regional centres: Renmark, Woomera, Kulgera (two nights), and then on to Uluru and Kata Tjuta (two nights). After that, Alice Springs (two nights); then on to the East MacDonnell Range and then the West MacDonnells, before beginning the long drive home, via Tennant Creek, Lightning Ridge, and Mudgee. There were many adventures 
(disasters) on the way which I have (or will) catalogue in various other publications. But my main aim was to collect as many local and regional newspapers as possible, in these centres, both free and paid for. Some I found in smaller townships between the larger centres, mainly at roadhouses.

My constraints were selecting data from the front page stories of the newspapers, including headlines; if the headlined story spilt onto the inside pages I could also use this text. My aim was to translate from the news story format to a piece of prose poetry in a bid to map the journey, capturing parts of the outback with meter and lyricism through found poetry. If it was successful on this reconnoitre, then the fully realised research project, circumnavigating the continent, was feasible.

Eighteen local or regional newspapers were collected en route. For the purpose of this paper, I have selected five front page stories, all from the Northern Territory, to apply the four types of found poetry (see below).

\section{A literary cartographic impulse as poetic synthesis}

The notion of writing as explorer resonates with this project. Peter Turchi writes, 'To ask for a map is to say, "Tell me a story" (2004: 11). He continues, explaining the two functions writing performs and, although non-sequential, he claims they are universal: exploration and presentation. He writes, 'If we do them well, both result in discovery' (2004: 12). Tally agrees with Turchi, his version: 'To draw a map is to tell a story, in many ways, and vice versa' (2013: 4). He writes:

The experience of being in the world is one of constant navigation, of locating oneself in relation to others, of orientation in space and in time, of charting a course, of placement and displacement, and of movements though an array of geographical and historical phenomena ...literary works serve a cartographic function by creating a figurative or allegorical representation of a social space, broadly understood. (Tally 2011: n.p.)

Tally draws heavily on Turchi's metaphorical earlier work in developing his own 'literary cartography' (2013: 50), and admits that narrative can be imposed on other forms of writing, including poetry. He writes:

As narrators or writers survey the territory they wish to describe, they weave together disparate elements in order to produce the narrative, and these elements may include scraps of other narratives, descriptions of people or places, images derived from first hand observation as well as from secondary reports, legends, myths and inventions of imagination. In producing this patchwork representation of a world, the narrator also invents or discovers the world presented ... for readers, this makes possible an image of the world, much like that of a map, and the literary cartography present in one narrative can become a part of future surveys, rhapsodies, and narratives, or of future narrative maps. (Tally 2013: 49)

Tally's literary cartographic thesis informs the heart of this research project. Legacy newspapers - the ones you actually hold in your hand, whose pages you can turn - are disappearing at an exponential rate across the globe. By melding the art of newspaper reporting with the art of prose found poetry, I hope to freeze in time a lyrical mapping 
of the country that can sit beside the news archives: an Australian 'literary cartography', to borrow Tally's phrase. James Joyce once said to friend Frank Budgen of his text Ulysses: 'I want ... to give a picture of Dublin so complete that if the city one day suddenly disappeared from the earth it could be reconstructed out of my book' (Budgen 1972: 69). Joyce is voicing his literary cartographic impulses. My poetic urge is not as intense, not nearly as forensic as Joyce's, but more closely aligned to TS Eliot when he writes: 'We shall not cease from exploration / And the end of all our exploring / Will be to arrive where we started / And know the place for the first time' (Eliot 1943: 47). The attempt is to provide a collection of cadenced nonfiction prose found poems, constrained by time and space; and to locate them on the map within the text, something significant on that day in that township or region, now appropriated from the local/regional newspapers. The attempt is to maintain the meaning of the original texts, but to deepen that meaning through a poetic prose lens, giving colour and voice to the regions. Burdick tells us: 'As written form changes, meaning subtly shifts ... Different ways of writing and seeing can jointly provide a more multidimensional discussion' (Burdick 2011: 2). Burdick positions the creation of this 'multidimensional' potential and 're-visioning' as a form of methodology. She writes, 'Found poetry has been used in numerous ways in qualitative research, both to formally present research process and findings, and through its use as another form of methodology and re-visioning a research text' (Burdick 2011: 3).

This research project is inspired by Webb when she writes: 'Poetry, thoughtfully and technically created, provides us with a notion of reality, and allows us to see, more clearly, how in our lived experience the elements of reality are constructed, and how they fit together' (Webb 2012: 10). Mulling over creative work as new knowledge, and writing from within the academy about the pressure to present creative work as such, Webb writes:

The very fact that poetry, for instance ... requires deep and sustained observation and deep and sustained reflection means it is likely to allow first the poet, and then the close readers of the poem, to see a little differently, to think a little differently, and thus to generate new ways of knowing and of doing. (Webb 2012: 6)

She writes of an ethical and social engagement and of readers appropriating this new way of thinking; this new knowledge, 'not to test it, not to apply remedies to society, but to revisit both thought and being' (Webb 2012: 9). Butler-Kisber likewise writes of her use of found poetry in research as offering something new: 'Whether found poetry is used as a public form of representation or as an analytic tool within the inquiry process, it will bring the researcher closer to the data in different and sometimes unusual ways that can yield new and important insights' (Butler-Kisber 2002: 235).

Taking words from newspaper stories and headlines, and reimagining them into poetry - deconstructing these 'elements of reality' in order to reconstruct them as another artefact - again evokes Eliot, who himself borrowed from many texts in The Wasteland (1922; dedicated to Ezra Pound) and other poems. He writes: 'One of the surest of tests is the way in which a poet borrows. Immature poets imitate; mature poets steal; bad poets deface what they take, and good poets make it into something better, or at least something different' (Eliot 1920: 114). Accordingly, poetry, whether found or 
otherwise, prose or verse, has maintained its cultural traction and indeed, burgeoned in past decades. As Burdick writes:

Poetry as a form is not only a different way of writing, it is a different way of presenting and viewing the world: metaphorically, symbolically and in a condensed form. These effects allow a stronger impressionistic meaning for the reader or listener. (Burdick 2011: 4)

\section{The Found Poetry Review ${ }^{2}$ + Fair Use}

The Found Poetry Review is an online journal, stating on its website that it 'celebrates the poetry in the existing and the everyday' (2016). It was launched in 2011, and accepts submissions all year round, claiming to publish just nine per cent for each issue. Editor in Chief Jenni B Baker is a poet in her own right. Writer Beth Ayer, the Senior Poetry Editor, also manages the website. There are seven poetry editors, a news editor and a book reviews' editor. The Found Poetry Review is a font of information about the process of fair use. According to the Review, there are four types of found poetry, which use various techniques including:

- Erasure: Poets take an existing source and erase the majority of the text, leaving behind select words and phrases that, when read in order, compose the poem.

- Free-form excerpting and remixing: Poets excerpt words and phrases from their source text(s) and rearrange them in any manner they choose

- Cento: Poets unite lines from other authors' writings into a new poem. The original lines remain intact; the main intervention comes in arrangement and form.

- Cut-up: Poets physically cut or tear up a text into words and phrases, then create a poem by rearranging those strips. Arrangement is intentional or haphazard.

(The Found Poetry Review 2016)

These are the techniques I am experimenting with and applying for this paper, testing each one on a front page headline story. I have written six poems: one erasure; two freeform and remixing; two cut-up; and one final cento, drawing from the first five poems written. Interestingly, the cento immediately renders itself as a fictional prose poem, but although sentences are taken from all five poems, it is still derivatively true of two of the nonfiction poems. Considering this, I believe for the larger project I will not be using the cento process for the final work, but may create a separate outcome of cento poetry with a different data gathering method.

On its website, the Center for Media and Social Impact states:

This code of best practices helps poets understand when they and others have the right to excerpt, quote and use copyrighted material in poetry. To create this code, poets came together to articulate their common expectations. (2011)

Their realisation was that 'the poetry community urgently needed to clarify for itself what best practices might be for fair use in poetry'. This is particularly pertinent for found poets, as they mine already-published artefacts for their work. Section 2 of the Code of Practice is tailored for this type of poetry. It is entitled New Works 'remixed' from other material: allusion, pastiche, centos, erasure, use of 'found' material, poetrygenerating software. I include the full description below: 
What is now called remixing is a contemporary version of allusion or pastiche and has long been an important part of poetic practice. In general, it takes existing poetry (or literary prose) as its point of reference. In some cases, however, the stuff of poetic remix may come from other sources, including (but not limited to) advertising copy and ephemeral journalism. Members of the poetry community also recognize that technology has extended the range of techniques by which language from a range of sources may be reprocessed as new creative work.

The coded principle states:

Under fair use, a poet may make use of quotations from existing poetry, literary prose, and non-literary material, if these quotations are re-presented in poetic forms that add value through significant imaginative or intellectual transformation, whether direct or (as in the case of poetry-generating software) indirect.

And its limitations are:

- Mere exploitation of existing copyrighted material, including uses that are solely 'decorative' or 'entertaining', should be avoided.

- Likewise, the mere application of computer technology does not, in itself, render quotation or re-use of an existing poem fair.

- If recognizable in the final product, quotations should be brief in relation to their sources, unless there is an articulable rationale for more extensive quotation.

- The poet should provide attribution in a conventionally appropriate form unless it would be truly impractical or artistically inappropriate to do so. (Center for Media and Social Impact 2011)

So with these further constraints in mind, I present my found poems below. 


\section{The poems found}

\section{Erasure poem}

The story by Tom Volling (2016: 1) is about the annual Apex Camel Cup, held in Alice Springs. The $47^{\text {th }}$ Cup was the first held since Cup co-founder Noel Fullerton died in late 2015. The front-page cover story under the masthead carries a bled-in photograph of a camel and Camel Australia's Neil Waters. The headline is: Speed Hump. Fiery rivalry ignites Camel Cup and continues onto page 5.

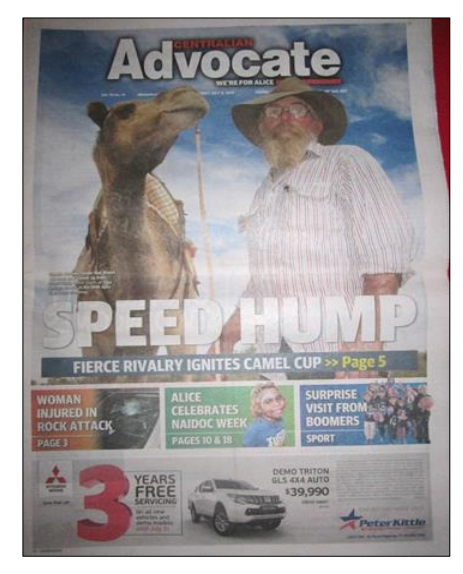

\section{Speed Hump}

Unpredictable and wacky camel spectacle: country's best camel jockeys; head to head eight-race card. Unique event in the centre of Australia: camels bring mayhem.

We live off tourism here so it is always good to put a little bit of money through the local communities to charities.

A tight track, a little heavier than others across the country, pretty short, pretty fast. Anything can happen: the camels zigzag; they weave; some sit down; some turn around; and go backwards.

A huge tourist crowd. 


\section{Free-form excerpting and remixing poem}

The second front page story chosen is the coverage of the shock accidental death of well-known cattleman, William 'Billy' Hayes, aged 46, in a plane crash on July 12, 2016, by Andrea Johnston (2016: 1). He was mustering cattle over New Crown Station in his Cessna 150 when the accident occurred. Held by a fifth-generation cattle family, Deep Well Station near Finke was established in the 1880s, and has stayed in the family ever since. The story is entitled Tragic Loss: Legendary Cattleman Dies in Plane Crash and continues onto page 3 .

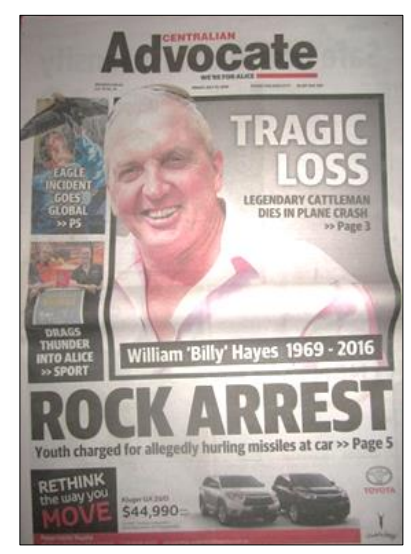

Tragic Loss

Billy Hayes will be sorely missed like his father. ${ }^{3}$ Mustering together, the ringers all on horseback; in his Cessna aircraft, Billy mustered. He was a brilliant horseman and skilled pilot. Enjoying life. Doing what he wanted to do, flying. An excellent and safe pilot; he loved flying.

Billy Hayes will be sorely missed, like his father, a passionate family man. His passion for his boys: he idolised those boys Luke 21; Tom 19; Sam 13; Harry 11 . Hour by hour, as the boys learn to deal - working through it day by day with the pain and grief. A family's devastation on Deep Well Station, Finke.

Billy Hayes will be sorely missed (like his father). Crashed in his Cessna 150. Crashed on Tuesday at $1 \mathrm{pm}$. Died.

Billy Hayes will be sorely missed. Like his father an infectious personality; just a good man; salt of the earth. All the Hayes' clan are.

Billy Hayes - easy going character; engaging like his father - will be sorely missed. Loved a good laugh; he would throw his head back and belly laugh. Humble, respectful, obliging, an icon: he lived his life as he should have.

Like his father, Billy Hayes will be sorely missed. 


\section{Free-form excerpting and remixing poem}

The story Strangers in Our Skies: Humpty Doo gardener left baffled after forces from above kill trees by Jill Poulsen (2016: 1) is about strange happenings on a property in Humpty Doo, owned by Mike Mewett. He is a gardener and a farmer but cannot explain a 100 metre stretch of trees that have been severely damaged and dying, not far from where a UFO was sighted by Brisbane UFO hunter Erik Black in 2010. The query is what has caused the damage. The page 1 story spills over to page 4 .

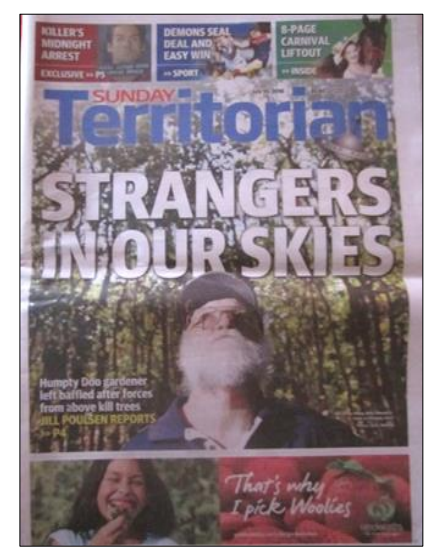

\section{Strangers in Our Skies}

What's been lurking in the Humpty Doo skies over his 2ha rural property? Avid gardener Mike Mewett noticed patches of leaves on trees on a roughly $100 \mathrm{~m}$ section of the property, were dropping. So strange, it's not the tree that's dying, it's like there's something been dropped on it from above ... forces from above kill ... a baffling case of dying foliage. Mewett said he'd never encountered anything like it. We sometimes see a light aircraft flying in the area ... maybe it dumped some fuel. To me that's the only logical explanation, unless we've got aliens around here. Less than a kilometre from where Brisbane UFO hunter Erik Black spotted a 'thing' shaped like a hamburger, with black dots and weirdlooking headlights floating above his head in 2010. Several sightings of round orbs hovering silently above Humpty Doo. The area is known for Yowie activity, but a local expert, (who asked not to be named) said there was 'no way' the damage could be put down to those creatures. It's far more likely to be a UFO than a Yowie he said. 


\section{Cut-up poem}

The story Dear Bradley, It's been 15 years since you killed Peter Falconio. Where is he? (Banks 2016: 1) is about the vicious attack on British backpackers Peter Falconio and his girlfriend Joanne Lees on 14 July 2001. Lees escaped their attacker but never saw her boyfriend again. He is presumed dead. Bradley Murdoch was found guilty in December 2005 of the attack and Falconio's murder, and sentenced to life in prison. He is currently serving his sentence at Darwin Correctional Centre in Darwin, Northern Territory. The story begins on page one, spilling over to page 2 .

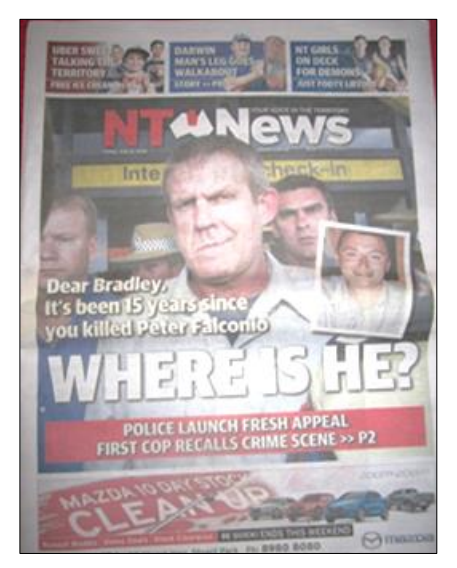

\section{Dear Bradley}

Kidnapped near Barrow Creek, on July 14 2001, 220km south of Tennant Creek; Peter Falconio and his girlfriend Joanne Lees. Lees escaped attack but never saw her boyfriend again. It's been 15 years since Peter Falconio was murdered. Bradley Murdoch found guilty of attacking the couple and murdering Falconio. Despite exhausting all lines of inquiry... Murdoch was one person who knew for certain where Falconio's body lay. The Falconio family's grief drove Territory police to follow new leads; no rest until his remains are found and returned to his family. What we can't ever exclude is with the weight of time and history certainly points at this for us - invariably somebody knows something. We remain committed to find where Peter's remains are so we can repatriate him with his family. The case would not be closed until the body was found. It remains open and will continue to remain open. We continue to call on Bradley to come forward to let us know where the remains are. No Body No Parole legislation prevents Murdoch from release unless he tells law enforcement where he left Peter Falconio.

Cold cases have sat dormant but of course there are people working away, looking at different bits of information as it comes.

It's been 15 years since Peter Falconio was murdered. 


\section{Cut-up poem}

The story I'll Never Forgive Michael (Palin 2016: 1) is about a talk Lindy ChamberlainCreighton gave in Sydney, comprehensively reported in the Northern Territory. This story, although syndicated, is displayed as a front page splash. This ownership of a narrative endures in the Territory, particularly with the Chamberlains and the story before, Peter Falconio's disappearance and presumed murder. I was surprised to see stories about both these cases on the front page, so many years after the facts. Chamberlain-Creighton speaks of resentment and bitterness in the aftermath of her arrest and jailing for life in 1982 for the murder of her daughter Azaria in 1980; her husband Michael $^{4}$ was found to be an accessory. The Chamberlains always claimed a dingo took their sleeping daughter, Azaria. Later evidence supported this claim, and Lindy Chamberlain was released from prison in 1986; the Chamberlains were pardoned in 1987; and in 1988, the Supreme Court of Darwin quashed all convictions. The headline I'll Never Forgive Michael is dramatic and she is not recorded as actually saying those precise words. The story spills over top page 2 .

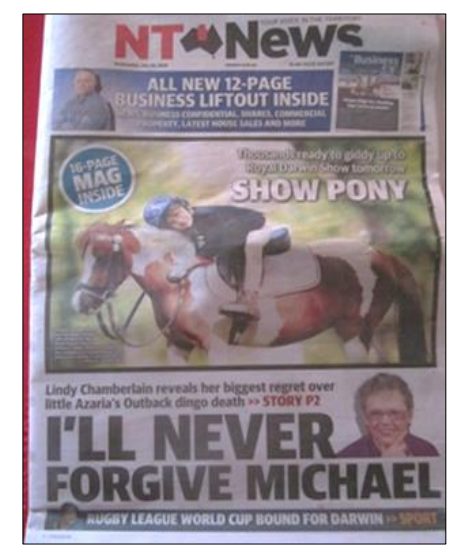

\section{I'll Never Forgive Michael}

Azaria's body has never been found.

Lindy Chamberlain-Creighton has been severely wronged by a lot of people. Wrongfully jailed for life over the murder of her baby Azaria after a dingo snatched her from an Outback tent - crept into the tent where the newborn and her little brother slept. Azaria's body has never been found.

Fought not to get stuck on bitterness and resentment. You can't get away from it. It sleeps with you at night. It goes to the bathroom with you. It showers with you. It has parties with friends with you. It's always there. Azaria's body has never been found.

You need to choose your battles wisely. Members of the Northern Territory Police, media, the general public and a jury, screamed bloody murder when nine-week-old Azaria went missing from a camp site at Uluru in 1980. Was it the NT? Police who pushed for a conviction? The media who blamed her? The judicial system that failed her? The public who wanted her blood? 
If you're holding the anger you're not hurting them. They're succeeding well beyond their wildest dreams. It's you that's dying. It's like mud, you can wash it off. Azaria's body has never been found.

It's my ex-husband I struggled most to forgive. In Sydney she said: That's private.

Lindy and Michael divorced in 1991. People often get involved in things and take sides with no knowledge. I've never felt I had to carry that pain. That's their responsibility. God and I knew the truth and that was enough for me. Because all the way through I felt absolutely positive that at some stage $\mathrm{He}$ would make sure that it all came out right. Azaria's body has never been found.

An inquest in 1980 found that a dingo killed Azaria but someone unknown later interfered with her clothes. A second inquest in 1982 and a trial. Lindy, found guilty of murder (sentenced to life in prison) and Michael, accessory after the fact (18 month suspended sentence). First in Mulawa Women's Prison and then in Darwin's Berrimah Jail - until a matinee jacket was found at Uluru in 1986.

The discovery: released from prison, and life sentence remitted by the Northern Territory Government.

Did I like to go to prison for something I haven't done? The answer is 'NO' with capitals. On the other hand would I change what I've gone through if I could no longer keep the lessons that I'd earned through that experience? The answer again is 'NO' in capital letters. Because what I've learnt is invaluable and I wouldn't swap that because that's made me who I am today. Azaria's body has never been found.

The Supreme Court of Darwin quashed all convictions and declared the Chamberlains innocent in 1998. In 2012 Azaria's death was officially ruled a result of her being taken by a dingo. Lindy and Michael fronted the Supreme Court in Darwin together and embraced outside. It had taken 32 years, four inquests, a trial, jail time, an exoneration, and a whole lot of heartache - but the case into Azaria's death was finally closed.

Azaria's body has never been found.

When you get a scar it hurts like hell but it eventually heals. You've always got it but it's no longer painful.

Azaria's body has never been found. 


\section{A Cento: combination from all five poems}

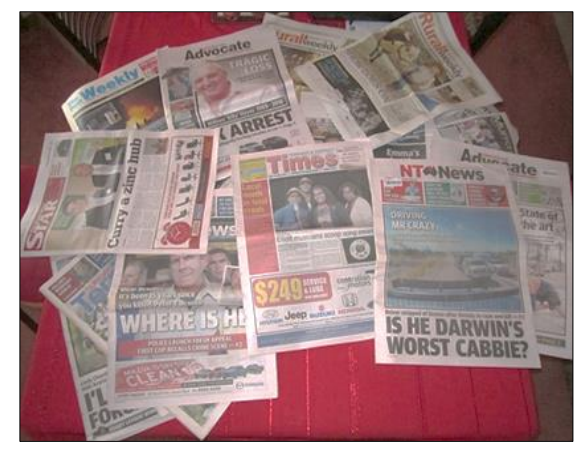

Forces from above kill

When you get a scar it hurts like hell but it eventually heals. As the boys learn to deal - with the pain and grief; working through it. Hour by hour, day by day. You've always got it but it's no longer painful. A unique event in the centre of Australia; mustering together, the ringers all on horseback; Billy mustered in his Cessna aircraft. Crashed at 1pm. Humble, respectful, obliging, an icon: he lived his life as he should have. He would throw his head back and belly laugh. A family's devastation on Deep Well Station Finke.

The body has never been found.

Come forward; invariably somebody knows something; let us know where the remains are.

Cold cases have sat dormant but of course there are people working away, looking at different bits of information as it comes. Despite exhausting all lines of inquiry, the answer is 'NO' with capitals: no rest until his remains are found and returned to his family.

The case would not be closed until the body was found. 


\section{Conclusion}

Like Prendergast, I have been 'caught' by this endeavour (2015: 682). Adhering strictly to the constraints of the four types of found poetry (The Found Poetry Review 2016), this creative practice has astounded and delighted me. Prendergast, in reflecting on her process of writing and selecting while creating found poetry, cites elements that attract her: aesthetic power; imagery, metaphor; capturing a moment; truth-telling, bravery, vulnerability; critical insight, often through empathy; surprise and the unexpected (Prendergast 2015: 683). I was aware at all times that my innate news sense as a former journalist dictated much of my selection; perhaps was my primary impulse (capturing a moment; truth-telling) in selection (Dear Bradley; I'll Never Forgive Michael; Tragic Loss). The sense of the odd or quirky that always captures my attention (surprise and the unexpected) was also clear in my selection (Camel Hump; Strangers in Our Skies). And I do believe my overarching impulse was aesthetic, in as much as the Northern Territory as an embodied entity, full of mystery and danger and romance and wide open spaces, informed my every memory and sharpened my sense of news story selection (and then word, sentence, paragraph selection) once back home. I imagine with a larger project the other elements Prendergast notes may become more apparent, but my project, steeped as it is in legacy media, no doubt is conceptualised through this innate interest.

As to the prose form, often found poetry is involved with finding prose texts and lineating them. I found that re-rendering journalism language into poetic language by rearranging whole sentences as well as selecting certain words lent itself naturally to the crafting of prose poetry. These poems could also be lineated, but for this preliminary research foray, I found the organic nature of prose poetry from journalism prose fluid and most effective.

By reconstituting legacy news of the day, my aim for the larger research project outcome will be a collection of found poetry with an idiosyncratic Australian voice, contextualised within regional and identifiable affect; I envisage each poem as a prose snapshot of a specified time period in each regional centre; a re-rendering of what was deemed important or newsworthy on each particular day in each particular place, eventually mapping the country with poetry. In this way, my objective is to 'know the place for the first time' as Eliot writes, through multiple modes of writing and reading, and to conserve this knowing as a way to 'celebrate the existing and the everyday' (The Found Poetry Review 2016).

As I hoped from this earlier research, the specific geographical constituents within each poem functioned as a map of our trip. Places mentioned are Sydney (our starting point); Finke (we were at the turn off to Finke while spending two nights in Kulgera), Uluru (two nights), Alice Springs (two nights), Barrow Creek (between Alice Springs and Tennant Creek); and Tennant Creek (one night). We did not make it to Brisbane or Humpty Doo, 40kms south of Darwin, nor to Darwin itself, instead turning right at Tennant Creek, and back to Sydney. Having successful outcomes from this recce, we hope they will be on our next trip. 


\section{Endnotes}

1. Charles Simic won the 1990 Pulitzer Prize for Poetry with The World Doesn't End, Harcourt Brace Jovanovich.

2. The Found Poetry Review closed March 2017; the site is still live and their journal issues are accessible.

3. Billy Hayes Snr died in a quad bike accident while mustering cattle in 2011; when she heard of her son's death in July 2016, Jan Hayes, 73, suffered a heart attack.

4. Michael Chamberlain died on 9 January 2017 at the age of 72.

\section{Works cited}

Bachelard, Gaston 1994 [1958] The poetics of space Boston: Beacon Press, 47

Banks, Kieran 2016 'Dear Bradley, it's been 15 years since you killed Peter Falconio. Where is he?' NT News (15 July): 1-2

Budgen, Frank 1972 James Joyce and the making of 'Ulysses', and other writings London: Oxford University Press

Burdick, Melanie 2011 'Researcher and teacher-participant found poetry: Collaboration in poetic transcription' International journal of education \& the arts 12, SI 1: Special Issue Selected Papers from the 2010 AERA Arts \& Learning SIG: 2-18 at http://www.ijea.org/v12si1/ (accessed 10 February 2017)

Butler-Kisber, Lynn 2002 'Artful portrayals in qualitative inquiry: The road to found poetry and beyond' Alberta journal of educational research XLVIII, 3: 229-39

Center for Media and Social Impact 2011 'Code of best practices in fair use for poetry' at http://cmsimpact.org/code/code-best-practices-fair-use-poetry/ (accessed 2 February 2017)

Delville, Michel 1998 The American prose poem: Poetic form and the boundaries of the genre Florida: University Press of Florida

Dillard, Annie 1995 Mornings like this: Found poems New York: Harper Collins

Dow, William 2016 'Profiles of lived experience: Charles Reznikoff, Muriel Rukeyser and Mark Novak' in S Joseph \& RL Keeble (eds) Profile pieces, journalism and the 'human interest bias' New York: Routledge, 116-37

Eliot, TS 1920 The sacred wood: Essays on poetry and criticism London: Methuen \& Co

Eliot, TS 1922 The waste land New York: Horace Liveright

Eliot, TS 1943 Four quartets New York: Houghton Mifflin Harcourt Publishing

Johnston, Andrea 2016 'Tragic loss: Legendary cattleman dies in plane crash' Centralian Advocate (15 July): $1 ; 3$

Johnson, Peter 1999 'Interview: The art of the prose poem Russell Edson' The prose poem: An international journal 8 at http://digitalcommons.providence.edu/cgi/viewcontent.cgi?article=1596\&context=prosepoem (accessed 2 February 2017) 
Lehman, David 2003 Great American prose poems: From Poe to the present New York: Scribner McDowell, Gary and Daniel F Rzicznek 2010 Field guide to prose poetry: Contemporary poets in discussion and action Massachusetts: Rose Metal Press

Monte, Steven 2000 Invisible fences: Prose poetry as a genre in French and American literature Lincoln: University of Nebraska Press

Palin, Megan 2016 'I'll never forgive Michael' NT News (20 July): 1-2

Poulsen, Jill 2016 'Strangers in our skies: Humpty Doo gardener left baffled after forces from above kill trees’ Sunday Territorian (19 July): 1; 4

Prendergast, Monica 2015 'Poetic inquiry, 2007-2012: A surrender and catch found poem' Qualitative inquiry 21, 8: 678-85

Tally, Robert T 2011 'On literary cartography: Narrative as a spatially symbolic act' NANO: New American notes online at http://www.nanocrit.com/issues/issue-1-navigation-all/literary-cartographynarrative-spatially-symbolic-act/ (accessed 6 June 2017)

Tally, Robert T 2013 Spatiality Oxon: Routledge

The Found Poetry Review 2016 'About found poetry' at http://www.foundpoetryreview.com/aboutfound-poetry/ (accessed 15 September 2016)

The Poetry Foundation 2016 'Glossary term' at https://www.poetryfoundation.org/ (accessed 15 September 2016)

Turchi, Peter 2004 Maps of the imagination: The writer as cartographer Texas: Trinity University Press

Volling, Tom 2016 ‘Speed hump: Fierce rivalry ignites camel cup' Centralian Advocate (8 July): 1; 5

Webb, Jen 2012 'Seeing, doing, knowing: Poetry and the pursuit of knowledge' TEXT Special Issue 13: Creativity: Cognitive, Social and cultural perspectives at http://www.textjournal.com.au/speciss/issue13/Webb.pdf (accessed 10 February 2017)

Wilkinson, Jessica and Ali Alizadeh 2012 'The realpolitik manifesto' Cordite poetry review at http://cordite.org.au/guncotton/the-realpoetik-manifesto/ (accessed 6 June 2017) 